\title{
The relationship between corporate ethics and organizational effectiveness, with an emphasis on municipal staff Region 1 Tehran
}

\author{
Leila ESMAEILI ${ }^{1}$, Akram SIANAKI ${ }^{2}$, Maryam ESMAEILI ${ }^{3}$, Shahram PASHAYI ${ }^{4}$, \\ and Mehdi Bay Ram Pour ${ }^{5}$
}

\author{
${ }^{1}$ Master of Educational Planning, Islamic Azad University, Tonekabon, Iran \\ ${ }^{2}$. Master of Urban Planning, PNU Rey Branch, Tehran, Iran \\ ${ }^{3}$ MA in geography and tourism planning, Islamic Azad University, Rasht, Iran \\ ${ }^{4}$ Management of Cultural Affairs, Islamic Azad University, Science and Research Branch, \\ Tehran, Iran \\ ${ }^{5}$ Master of Public Administration, Islamic Azad University Central Tehran Branch Tehran Iran
}

\begin{abstract}
Increasingly more complex operations and the immoral, illegal and irresponsible managers and experts to discuss ethics in the workplace and ethical management has brought. Ethics management is to identify and prioritize values to guide the behavior of the organization. Organizations by creating an ethics management program can manage ethics in the workplace. Ethics programs help organizations so they can maintain their ethical performance in turbulent conditions. The ethical management of scientific management is an approach that has several programs and practical tools. The aim of this study was to determine the relationship between corporate ethics and organizational effectiveness municipal staff in Tehran. The study correlated the population of the municipality of Tehran all staff to 750 people. Of the sample of 173 persons were selected using random sampling method were studied. The scale of corporate ethics to collect data reliability 945 /. And organizational effectiveness with reliability coefficient of 961 /. Used. Data correlation coefficient, multivariate regression analysis were analyzed. The findings of the study showed that among the components of organizational ethics (the political, social, economic and public) and organizational effectiveness staff Tehran municipality a positive and significant relationship exists. $\mathrm{P}<0 / 01)$. And the composition of each of these variables could explain 61 percent of the variance. The predictive variables, the most useful component of the economic dimension of corporate ethics that alone 53\% (R2) of predicted changes in organizational effectiveness. While the share of other variables, only about $8 \%(53 \%-61$ percent).
\end{abstract}

Keywords: corporate ethics, organizational effectiveness, the political dimension of social, economic and ethical public

\section{Introduction (problem statement)}

As a system of values and ethics in the organization Dos and Don'ts defined according to which good and bad organization and bad practice is distinguished from good. In general humans in the personal and moral character has a special feature that thoughts, words and actions that shape them. It is possible when these people are in a position and organizational position causes 
that thought, speech and behavior of individual human turn these features effect on the efficiency and effectiveness of the organization. Ethical different behaviors of individuals as employees, a head office health and the other is corruption is analyzed. And Integrity in the success of the organization in carrying out missions, implementation of strategies and programs and ultimately achieve organizational goals plays an important role. The first step in achieving these goals correct understanding of moral and ethical behavior of employees in an organization is to identify factors influencing (jurists and Rezaeemanesh, 1384). Hunt and colleagues have created the concept of moral values and ethical values, cultural characteristics describes the moral sphere. Studies have shown that individuals' perception of the currency and ethical management methods positively associated with certain moral beliefs. Employees prefer organizational environment with ethics. The public response to ethical values increase staff to work with the values of the organization and on the other hand committed employees often have communication and connectivity (Valentine et al, 2002, quoted Abbas and Khodayari, 1390). Demographic consequences of ethical behavior in the workplace is diverse and numerous, Moral development also has different meanings in different cultures and content. Different cultures in the world have fundamental differences with each other. Effective organization capable of managing ambiguity, flexibility, customer focus, production, The Value of structured learning and employment and empowerment of employees to identify the main area (between Oei et al. 2007, quoting A. et al., 1391) . Organizational effectiveness is the extent to which an organization uses its own resources In fact, organizational effectiveness, the closer grade shows an organization's goals (Zahedi et al., 1379). In other words, the extent to which an organization realizes its goals (Zheng et al., 2010).without wasting resources, its members and the community meets its goals (T-ment and Fvyla, 1996). Organizational effectiveness lies in the processes and management methods and organization are highly successful in terms of organizational design has three characteristics, namely: a simple, small staff, decentralization aimed at increasing entrepreneurship (quoted from Seifi Saldhy, 1391). In fact, organizational effectiveness is a general concept and determine the effectiveness of an organization, or the amount that multiple targets are provided approximately evaluated or measured and judged (Daft, translation Parsaeian and the Arabs, 1386). It should be noted the value system in improving organizational performance. Because their value system when deciding factors that directly affect the behavior of employees. Therefore, guidance and training in order to obtain a more value based system can cause their desirable functions as a result leads to organizational effectiveness (Robbins, 1375).

\section{The importance of research}

Among the factors influencing the development of communication skills managers' moral existence. Ethics, honesty and integrity of critical skills and business skills, and the incidence of these factors are helpful in communications (Long Lewis and Lapvynt, 2010). Ethics education goals are enhancing the ability of learners to better understand the results of activities in relation to others (Louth, 6: 2011). Ethical organization leads to efficiency and effectiveness of any organization is more moral, more successful. Increase productivity and efficiency, creativity and innovation, leading to integration and solidarity, improve quality, and pay more attention to staff, prevent corruption and misuse of power Ethical business is based. Thus, corporate ethics is an important role on organizational effectiveness (Samir Ahmad, 2009). 


\section{The objectives of the study (in line with the hypothesis) The main purpose}

Examine the relationship between organizational ethics and organizational effectiveness staff of Tehran Municipality.

Partial goals

1. Investigate the relationship between the political dimension of organizational ethics, organizational effectiveness

2. Examine the relationship between the social dimension of organizational ethics, organizational effectiveness

3. Evaluation of the economic relationship between organizational ethics and their organizational effectiveness

4. Public Ethics investigate the relationship between organizational dimensions of organizational effectiveness staff

\section{The definition of variables}

Organizational Ethics: Ethics is the study and practice of corporate ethical behavior in organizations including the description and evaluation of policies and practices rooted in traditional values and Search Tool for morality is the high performances (Caroline and Chris, 2007). Organizational effectiveness, organizational effectiveness is a situation where the organization to consume a limited amount of resources, and be able to achieve its objectives according to set criteria (howdah and Anthony, 1998).

\section{Operational definitions of variables}

Corporate ethics: a score that participants acquire corporate ethics questionnaire.

Organizational Effectiveness: the subjects of organizational effectiveness questionnaire score you get.

\section{Organizational Effectiveness}

Organizational effectiveness, organizational development plays an important role in the effective organization capable of managing ambiguity, flexibility, customer focus, production, The Value of structured learning and employment and empowerment of employees to identify the main area (between Avi and others , 2007, quoted by Ardalan et al., 1391). Organizational effectiveness is the extent to which an organization using specific resources without wasting their resources without unnecessary wear and community members, meets its goals (T-ment and Fvyla 1996). In fact, organizational effectiveness, the closer grade shows an organization's goals (Zahedi et al., 1379). In other words the extent that an organization gives those objectives (War and others, 2010). Organizational effectiveness and individual of the same concept, but a very complex issue that includes the preferences and expectations are different (Herman and Ronse, 2004). Organizational effectiveness lies in the processes and management methods and highly successful organization in terms of organizational design has three characteristics are as follows: Is simply a small staff, decentralization aimed at increasing entrepreneurship (quoted from Seifi Saldhy, 1391). In fact, organizational effectiveness is a general concept and determine the effectiveness of an organization, or the amount that multiple targets are provided approximately evaluated or measured and judged (Daft, translation Parsaeian and the Arabs, 1386). 
Table 1: Sample MOE selected organizations, through strategic stakeholder in a business

\begin{tabular}{|c|l|}
\hline Beneficiary & \multicolumn{1}{c|}{ Standard samples } \\
\hline Owner & Rate of return on investment, revenue growth \\
\hline Employees & How compensation (fees), benefits, satisfaction with working conditions \\
\hline customers & Satisfaction with price, quality and service \\
\hline $\begin{array}{c}\text { Raw material } \\
\text { suppliers }\end{array}$ & The satisfaction of payment, expected sales \\
\hline Lenders & Ability to pay debt \\
\hline Unions & $\begin{array}{l}\text { Competitive pay and benefits, working conditions satisfactory, fair collective } \\
\text { bargaining }\end{array}$ \\
\hline State institutions & Obey the rules. Prevention of crimes and offenses \\
\hline
\end{tabular}

Source: (Daft, translation Parsaeian and the Arabs, 1386)

\section{Society, and methods of sampling}

The study population included all employees of the municipality of Tehran to 750 people. The sample was selected by taking a few features. First, the similarities and homogeneity of all nurses are members of the statistical community which is at a high level. Second, the number of main variables and assumptions used to estimate the sample size is also good measure. There are five variables in this study and most experts believe the number of 30-40 individuals for each variable in a correlational study is appropriate. By taking into account the homogeneity of the population and number of 40 participants for each variable is ultimately intended sample size of 200 people. Who were selected by simple random sampling after completing the questionnaires, 27 questionnaires were rejected, and was excluded from the analysis result of 173 questionnaires were analyzed.

\section{The validity and reliability of data collection}

1. Inventory corporate ethics (ethics or professional): validity by faculty and advisors and other professionals is reviewed and approved. The validity by Coronbach's alpha equal to 945 /... Is.

2. Organizational effectiveness questionnaire: validity by faculty and advisors and other professionals is reviewed and approved. The validity by Coronbach's alpha equal to 961 I. Is.

- Inventory corporate ethics (ethics or professional): This questionnaire consists of 34 items and four factors (political, social, economic and public) that for the whole Likert from very low (1) to very high (5) is. The purpose of this questionnaire is organizational ethics. The questionnaire based on the strategic aspects of the cultural elements of the Cultural Revolution by Rumi et al (1391) made four political dimension (questions 1 to 8), social (questions 9 and 14), the economy (15 to 26 ), public (27 to 34 ) can measured.

- Organizational Effectiveness Questionnaire: This questionnaire has 28 questions five-item Likert range from very low (1) to very high (5), based on four essential functions of the social system, Parsons (AGIL) is set to include four components (compliance business purpose, unity and maintain the pattern) is. The components of superposition (Questions 21-18-16-15-13-11-6), target acquisition (Questions 17-14-12-7-5-2-1), unity (22-20-10-3 questions) and to maintain the pattern (questions 28-27-26-25-24-23-19) measures.

\section{Research findings}

Data distinguished with descriptive tables used to describe the variables. In the data analysis, hypothesis testing and statistical tests, Pearson correlation and multivariate regression analysis were used. Linear relationship between quantitative variables and Pearson correlation coefficient 
showed that in a sample. Also, students must have grades for each variable, the significance test for the presence or absence of a linear correlation between the two variables determine the community. A statistical method that allows us to score one person at a variable based on her scores on the other variable or multiple variables in the regression is correlated to foresee how. No matter how grades are better correlated to the regression line is closer and therefore more accurate prediction. When regression can be used to:

1. Linear relationship exists between dependent and independent variables.

2. The dependent variable is measured based on the distance scale.

3. The independent variable is measured on interval scale or rank. Descriptive statistical characteristics of the studied variables are presented in Table 2.

Table 2: Descriptive statistical characteristics of the variables studied $(n=173)$

\begin{tabular}{|c|c|c|}
\hline The standard deviation & Average & Variables \\
\hline $16 / 992$ & $83 / 23$ & Organizational effectiveness \\
\hline $5 / 925$ & $22 / 54$ & The political dimension of ethics \\
\hline $4 / 843$ & $18 / 60$ & The social dimension of ethics \\
\hline $8 / 989$ & $32 / 54$ & The moral economy \\
\hline $6 / 874$ & 22.2 & After ethical public \\
\hline
\end{tabular}

As seen in the table above the average of the dependent variable organizational effectiveness $83 / 23$ and 16/992 with a standard deviation of independent variables highest index component to the economic dimension of corporate ethics standard deviation and the accompanying 8/889 and $57 / 32$ and the lowest ones the social dimension of corporate ethics component to the value $60 / 18$ with the standard deviation is $4 / 843$.

Table 3: questions to test the results of the correlation coefficient considered and each of them will look.

\begin{tabular}{|c|c|l|}
\hline $\mathbf{p}$ & $\mathbf{r}$ & \multicolumn{1}{|c|}{ Variable } \\
\hline $000 / 0$ & $0 / 692$ & Political dimension. Morality \\
\hline $000 / 0$ & $0 / 693$ & Social dimension. Morality \\
\hline $000 / 0$ & $0 / 732$ & Economic dimension. Morality \\
\hline $000 / 0$ & $0 / 683$ & General later. Morality \\
\hline \multicolumn{2}{|c|}{$0.01>\ll \ll P, 05 / 0>$ « } \\
\hline
\end{tabular}

To determine the best predictor of organizational effectiveness of the regression model between the predictor variables and partial correlation with the same method is used. The results are presented in Table 4. 
Table 4: squared correlation coefficient of multiple and multi-component variables in predicting corporate ethics and organizational effectiveness

\begin{tabular}{|c|c|c|c|c|c|c|}
\hline $\begin{array}{c}\text { Significance } \\
\text { level }\end{array}$ & $\begin{array}{c}\text { Factor } \\
(168,4) \\
\mathrm{f}\end{array}$ & $\begin{array}{c}\text { Square } \\
\text { multiple } \\
\text { correlation } \\
\text { coefficient } \\
\text { adjusted }\end{array}$ & $\begin{array}{c}\text { Square } \\
\text { multiple } \\
\text { correlation } \\
\text { coefficient }\end{array}$ & $\begin{array}{c}\text { Multiple } \\
\text { correlation } \\
\text { coefficient }\end{array}$ & $\begin{array}{c}\text { The dependent } \\
\text { variable was }\end{array}$ & $\begin{array}{c}\text { Variable - } \\
\text { criterion }\end{array}$ \\
\hline $0 / 000$ & $67 / 418$ & $0 / 607$ & $0 / 616$ & $0 / 785$ & $\begin{array}{c}\text { After ethical } \\
\text { public, political } \\
\text { dimension of } \\
\text { ethics, social } \\
\text { ethics, the moral } \\
\text { economy }\end{array}$ & $\begin{array}{c}\text { Organizational } \\
\text { effectiveness }\end{array}$ \\
\hline
\end{tabular}

According to the above table the relationship between public after corporate ethics, organizational ethics, political aspect, social aspect of corporate ethics, corporate ethics economically significant in predicting organizational effectiveness $(000 / 0=p, 418 / 67=) 4,168)$ $=\mathrm{F})$. The linear combination of values significantly associated with organizational effectiveness. The correlation coefficient, multiple sample 785/0 shows that almost 61 percent of the variance in organizational effectiveness in the sample is explained by a linear combination of organizational values Ethical dimensions $(616$ / 0R2 =). Therefore, it was concluded that the independent variables public after corporate ethics, the political dimension of organizational ethics, corporate ethics social dimension, economic dimension. Corporate ethics criterion variables have predictive power. The regression equation is generalized to the entire population. The results for the coefficients and regression analysis to determine the independent significant predictor variables and the regression equation set is presented in Table 5.

Table 5: standard and nonstandard regression coefficients for the prediction of organizational

effectiveness

\begin{tabular}{|c|c|c|c|c|c|c|}
\hline $\begin{array}{c}\text { Level } \\
\text { meaningful }\end{array}$ & $\mathbf{T}$ & $\begin{array}{c}\text { Factor } \\
\text { Standard } \\
\text { Beta }\end{array}$ & $\begin{array}{c}\text { standard } \\
\text { error }\end{array}$ & $\begin{array}{c}\text { Custom beta } \\
\text { coefficients }\end{array}$ & $\begin{array}{c}\text { Statistical } \\
\text { Indicators } \\
\text { Predictor } \\
\text { variables }\end{array}$ & $\begin{array}{c}\text { Variable } \\
\text { Criterion }\end{array}$ \\
\hline $0 / 000$ & $8 / 365$ & $0 / 000$ & $3 / 484$ & $29 / 145$ & constant number & $\begin{array}{c}\text { Organizational } \\
\text { effectiveness }\end{array}$ \\
\hline $0 / 000$ & $3 / 603$ & $0 / 266$ & $0 / 212$ & $0 / 764$ & $\begin{array}{c}\text { The political } \\
\text { dimension of ethics }\end{array}$ & $\begin{array}{c}\text { The social } \\
\text { dimension of ethics }\end{array}$ \\
\hline $0 / 043$ & $2 / 042$ & $0 / 171$ & $0 / 295$ & $0 / 602$ & $\begin{array}{c}\text { The moral } \\
\text { economy }\end{array}$ & \\
\hline $0 / 010$ & $2 / 594$ & $0 / 249$ & $0 / 182$ & $0 / 471$ & After ethical public & \\
\hline $0 / 025$ & $2 / 762$ & $0 / 190$ & $0 / 207$ & $0 / 469$ & & \\
\hline
\end{tabular}

According to the results presented in Table $\mathrm{F}$ in the table above and meaningful analysis of variance (4-3) and $t$ in the above table Regression equation with all four predictors of organizational ethics significantly related to organizational effectiveness. According to the slope coefficients (column B) regression equation will be as follows. 


$$
\mathrm{Y}=\mathrm{A}+\mathrm{b}_{1} \mathrm{x}_{1+} \mathrm{b}_{2} \mathrm{x}_{2} \mathrm{~b}_{3} \mathrm{X}_{3+\cdots}
$$

So by replacing the coefficients in the above formula, the equation predicted the organizational effectiveness of the variable component values of corporate ethics can be obtained as follows.

\section{- Predict organizational effectiveness}

(Later General) 469/0 + (economic dimension) 471/0 + (social dimension) 602/0 + (politically) $764 / 0+145 / 29$. Given the amount of tilt, the values of all dimensions of organizational ethics are more variable components for organizational effectiveness predicts. Indicators presented in Table 6 shows the relative ability of each predictor.

Table 6: bivariate correlations and partial predictor of organizational effectiveness

\begin{tabular}{|c|c|c|}
\hline Partial relationships & Solidarity, dual variable & Variable \\
\hline $268 / 0 * *$ & $692 / 0 * *$ & The political, organizational ethics \\
\hline $156 / 0 *$ & $693 / 0 * *$ & Social, organizational ethics \\
\hline $196 / 0 * *$ & $732 / 0 * *$ & Economic, organizational ethics \\
\hline $172 / 0 *$ & $688 / 0 * *$ & General, corporate ethics \\
\hline
\end{tabular}

Dual correlation: the correlation of each predictor and organizational effectiveness Partial relationships: between each predictor and organizational effectiveness by controlling for other predictors of

$$
\mathrm{P}^{* *}<.01, \mathrm{p}^{*}<.05
$$

As can be seen in the bivariate correlations between all four levels of organizational effectiveness and organizational ethics component is significant positive correlation $(01 / 0>P)$. And the partial correlations between the values of the four components of organizational effectiveness and organizational ethics, corporate ethics all components of meaningful (05/0> P). According to the correlation analysis, this result can be predicted that more useful, corporate ethics is the economic component alone 53\% (R2) of the predicted changes in organizational effectiveness. While the share of other variables, only about 8 percent $(53 \%-61 \%)$ is. According to the research hypotheses examined data table.

The main hypothesis: there is a relationship between corporate ethics and organizational effectiveness.

According to data calculated correlation coefficients in Table $601 / 0 \mathrm{P}<$ significant $(000 / 0=\mathrm{P}$, 785 / 0r =). Show that between organizational ethics and there is a significant positive relationship with organizational effectiveness. In other words, no matter how organizational effectiveness will increase organizational ethics.

First hypothesis: the political dimension of organizational behavior and organizational effectiveness they are related.

Based on the data from Table 4-2 calculated correlation coefficients between the components of the political dimension of organizational behavior and organizational effectiveness at the level of 01 / OP < positive relationship significant) $000 / 0=p, 692$ / 0r =) In other words, whatever the political dimension of organizational ethics will increase their organizational effectiveness will increase. The result is shown in the following diagram. 


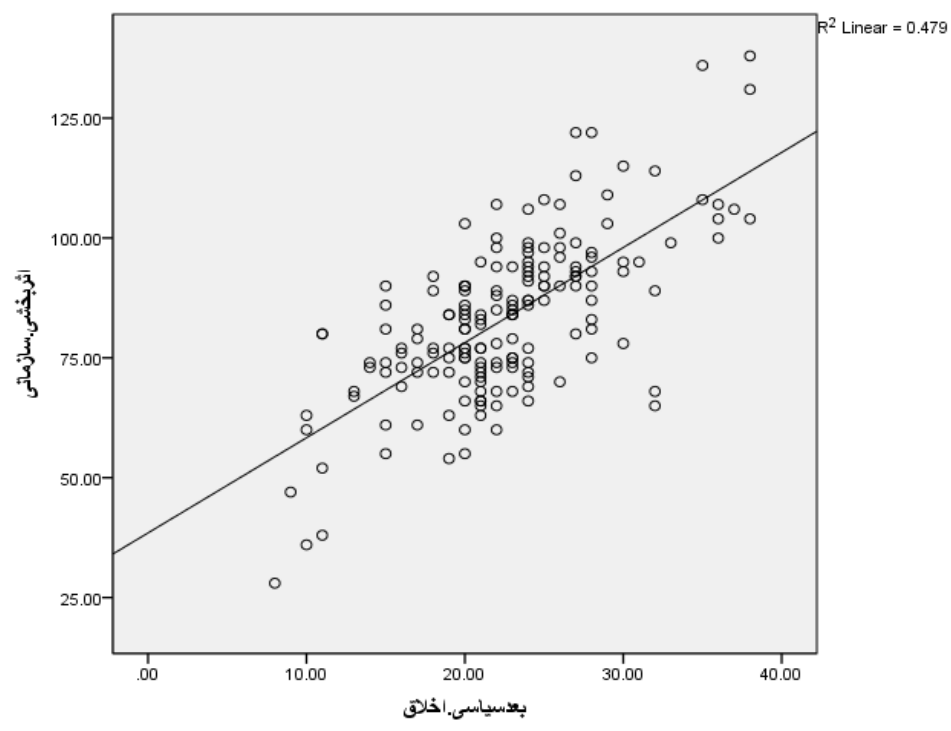

Figure 1: Diagram of the political dimension of correlation between corporate ethics and organizational effectiveness

The second hypothesis: relationship between the social aspect of corporate ethics and organizational effectiveness of their staff there.

Based on the data in Table 6 calculated correlation coefficients between the components of the social dimension of organizational behavior and organizational effectiveness at the level of $01 / 0 \mathrm{P}<$ relationship is positive and significant. $(000 / 0=\mathrm{p}, 693 / 0 \mathrm{r}=)$ In other words, no matter how the social dimension of organizational ethics increase their organizational effectiveness will increase. The result is shown in the following diagram.

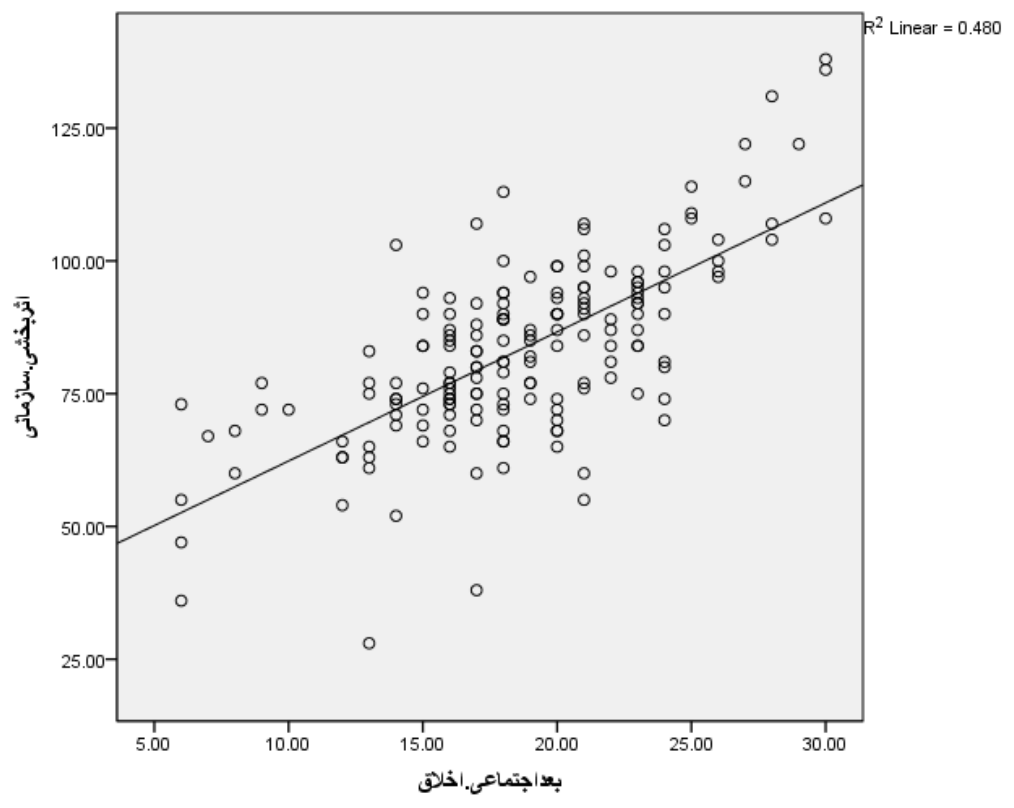

Figure 2: Diagram correlation of the social dimension of corporate ethics and organizational effectiveness 
The third hypothesis: the economic dimension of organizational behavior and organizational effectiveness they are related.

Based on the data from Table 4-2 calculated correlation coefficients between the economic component of organizational behavior and organizational effectiveness at the level of $01 / 0 \mathrm{P}$ <relationship is positive and significant. ) $000 / 0=\mathrm{p}, 732$ / $0 \mathrm{r}=$ ) In other words, whatever the moral economy also increased their organizational increased organizational effectiveness. The result is shown in the following diagram.

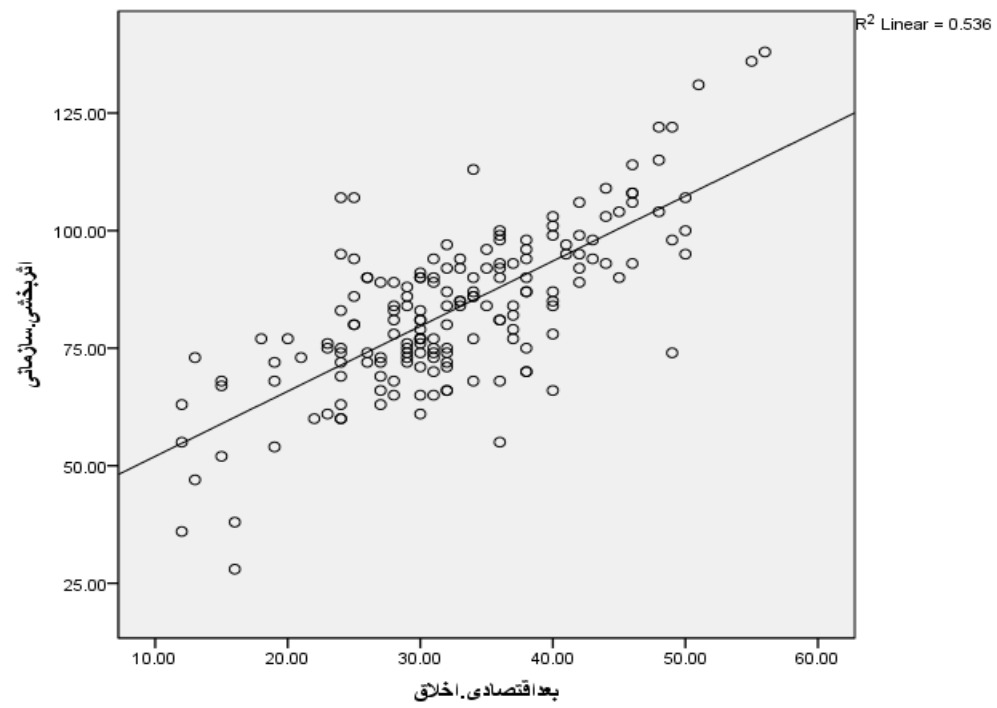

Figure 3: Diagram of the economic correlation between corporate ethics and organizational effectiveness

The fourth hypothesis: between the organizational ethical public relations staff and their organizational effectiveness there.

Based on the data in Table 6 calculated correlation coefficients between the public component of organizational behavior and organizational effectiveness at the level of $01 / 0 \mathrm{P}$ <relationship is positive and significant.) $000 / 0=\mathrm{p}, 688 / 0 \mathrm{r}=$ ). In other words, whatever the organizational ethical public employees will increase their organizational effectiveness will increase. The result is shown in the following diagram. 


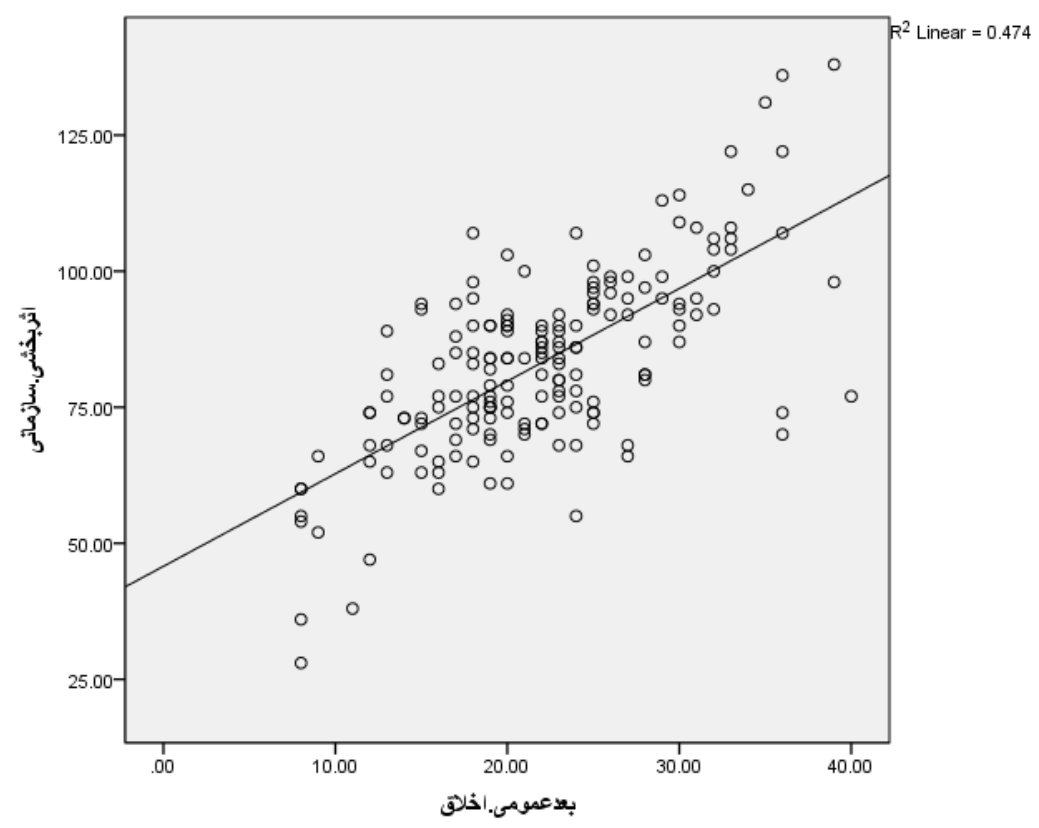

Figure 4: correlation charts of the public corporate ethics and organizational effectiveness.

\section{Conclusion}

Organizational ethics as a scientific concept in various levels of individual and organizational researchers in the past four decades has attracted, that as a major challenge facing organizations all over the world will be different. Ethical organization leads to efficiency and effectiveness of any organization is more moral, more successful. The aim of this study was to determine the relationship between corporate ethics and organizational effectiveness municipal staff in Tehran. The study correlated the population of all employees in the municipality of Tehran was 750, of the sample of 173 persons were selected using random sampling method were studied. To collect the data, the scale corporate ethics and organizational effectiveness were used. Data correlation coefficient, multivariate regression analysis were analyzed.

\section{Research proposals}

Given that corporate ethics among employees to increase their effectiveness in the organization. Therefore, the following recommendations are provided to improve corporate ethics:

- New staff during her time with the organization are consistent with the ethics of illustrations.

- The training courses will be held for managers to review ethics management program pay.

- Allow employees to review company policies, ethics and personnel policies, was a strong education.

- One of the best forms of moral ethics training to their employees to practice in solving complex problems. It can be real or simulated reality of a moral dilemma presented to them and asked them to investigate and resolve ethical dilemmas using the methods it has been discussed and solutions provider.

- Of performance evaluations ethical performance as well as one of the aspects of it.

- Note that with all this said, the best trainers, leaders of the organization. 


\section{References}

1. Kazmabad Ebrahimi, A. (1386). Investigate the relationship between moral development and altruistic tendencies of personality dimensions in coping with stress in high school students in Tehran, Master Thesis, University martyr Beheshti.

2. Ebrahimpour, purpose (1387), "The Relationship between managers' motivation to organizational effectiveness in schools zones 1 and 2 Urmia", MSc thesis, University of Urmia

3. Abzari, M and Sraydaryan, Hamid. (1376) .mdyryt organizational behavior "organization, management and psychological pressure" of company research process.

4. Ibn Sina, 1404, Healing (logic), Qom, Find your Marashi.

5. Ardalan, MR; Eskandari, A., Gilani, Mary (1391), knowledge management, organizational intelligence and organizational effectiveness, strategic management studies, Issue 21, Winter, pp S71-100.

6. Scott, R... 1375, organizations: legal systems, natural and open, translation MR Behrangi (brass), Volume II, Publishing Perfection Training, Tehran.

7. Qadavvd, R., 1385, effective supervision and administrative services industry organizations, Second Edition, published by Sonnet, Isfahan.

8. Righteous, K., 1382, Human Resources Management and the Department of Employment, Tehran, Cognizant.

9. Pour Kiani, M., Gholami, M. (1392), explores the relationship between positive employee behaviors and organizational effectiveness executive dairy Drdstga city of Birjand, monthly social, economic, scientific and cultural and community, Issue 157, June.

10. Hassani, Mohammed, Summer, M. (1389), examining organizational effectiveness secondary schools in Urmia region a model Parsons, management, organizational culture, Issue Twenty-One, Spring, Summer, pp. $201-223$.

11. Hamid, M., (1382). The relationship between organizational structure, organizational commitment and organizational effectiveness in the areas of Organization

12. soil, GR (1388), The alchemy of happiness Nations Ethics Roundtable, a monthly measure

13. East, Mehdi. (1386). Explain the relationship between ethics and staff performance petroleum products distribution company in Iran and the region, Tehran Allameh Tabatabai University.

14. East, SM. (1386) .tbyyn relationship work ethic and performance Iranian Oil Products Distribution Company employees and the region, Tehran Allameh Tabatabai University.

15. Daft Richard L. (1374 Sb.), Organizational theory and design structure, the translation of the Persians and the Arabs, Tehran, commercial publishing company. 